\title{
イラク土壤より分離された釆状菌の毒性検索および マイコトキシン生産性
}

前林 行雄*1, 堀江 義一 ${ }^{* 1}$, 山崎 幹夫*1

\author{
Y. MAebayashi*1, Y. HoRIE*1 M. YAMAZAKI ${ }^{* 1}$ : Productivity of \\ some mycotoxins in fungi isolated from Iraqi soil
}

\begin{abstract}
Summary
From the 20 soil samples collected at date-plantation in Iraq, 56 molds were isolated. The fungal species were Aspergillus flavus, A. caespitosus, A. fumigatus, Emericella nidulans, E. variecolor, E. acristata, Chaetomium spp., and the other Ascomycetes and Deuteromycetes. The lethal toxicity of ethyl acetate extracts of the moldy rice was examined by intraperitoneal injection to mice. Many of the molds were found to be toxigenic. By TLC analysis, the productivity of aflatoxin, sterigmatocystin, asteltoxin, verruculogen and fumitremorgin was confirmed on some of the isolates. A new toxic metabolite, tentatively designated as EQ-1, was isolated from Emericella quadrilineata strain No. 83-Ir-4-7.
\end{abstract}

著者らは，てれまでに主として食品を污染する有害 系状菌を探索し，それらより毒性代謝産物を単離して その化学構造を明らかにしてきだ ${ }^{1) 8}$. 近年, 食品, 飼料などのマイコトキシン污染に関連して，とくに土 塨中のマイコトキシン生産菌の存在が注目され，ピー ナッツのアフラトキシン污染とピーナッッ畑の土塨中 のアフラトキシン生産菌との生態的研究が報告されて いる゙．著者らあ日本国内土塞における Aspergillus fumigatus の分布調査およびその fumitremorgin 類 の生産性について報告しだ).

今回は, イラクのデーツ (東楖子) 畑の土塨を入手 する機会を得たので系状菌を分離して，そのマイコト キシンの生産性およびマウスに対する致死毒性につい て検索した．その結果につき報告する.

\section{材料および方法}

土㙗菌の分離：イラクのバスラ市郊外のデーツ（東 楖子）畑より採取した土塨サンプルからジャガイモ・ ニンジン寒天, オートミル寒天, ジャガイモ・ブドウ 糖寒天培地を用いた soil plate 法にて糸状菌を分離し

* 千葉大学生物活性研究所 ( 8-1)

Reseach Institute for Chemobiodynamics, Chiba University (Inohana 1-8-1, Chiba 280)
た.

培養・抽出：各々の菌株をルーフラスコに入れた精 白米培地に接種し， $25^{\circ} \mathrm{C}$ で約 3 週間 静置培養した。 接種 5 日後, 各々のフラスコに $30 \mathrm{ml}$ の滅菌蒸留水を 注入した. カビ米を酢酸エチルで抽出, 減王濃縮して エキスを作成した。

マイコトキシンの検索: 各々の抽出エキスを TLC プレート（メルク・プレコート・シリカゲル 60）に 既知マイコトキシン標品ととあに 展開し UV ランプ 下の螢光または $10 \%$ 硫酸を噴霧し加熱, その呈色で 判定した.

毒性試験：毒性試験は 5 週齢の ddY 系雄マウス(体 重 $23 \sim 27 \mathrm{~g}$ ）を使用した. サンプル はプロピレング リコールに溶かし, $500 \mathrm{mg} / \mathrm{kg}$ 腹腔内投与した.

\section{結果および考察}

イラクの土塞 20 試料より分離した 56 株を米に培 養, その抽出エキスのマイコトキシンと毒性検索の結 果を Table 1, 2 に示した.

Emericella 属の菌が比較的強い毒性を示した. な かです E. variecolor のエキスが投与後数分でマウ スを死亡させる強い毒性を示し，TLC 検索で asteltoxin の生産が認められた．また，E，quadrilineata の全株に毒性が認められ, 83-Ir-4-7 株の培養抽出エ 
Table 1. Productivity of some mycotoxins in fungi isolated from Iraqi soil

\begin{tabular}{|c|c|c|c|c|}
\hline Species & Strains & died/used* & Mycotoxins & \\
\hline Emericella nidulans & $\begin{array}{l}83-\mathrm{Ir}-1-2 \\
83-\mathrm{Ir}-3-1 \\
83-\mathrm{Ir}-3-2 \\
83-\mathrm{Ir}-3-3 \\
83-\mathrm{Ir}-4-13 \\
83-\mathrm{Ir}-5-8 \\
83-\mathrm{Ir}-5-10 \\
83-\mathrm{Ir}-5-13 \\
83-\mathrm{Ir}-7-3 \\
83-\mathrm{Ir}-7-5\end{array}$ & $\begin{array}{l}1 / 5 \\
4 / 5 \\
4 / 5 \\
3 / 5 \\
5 / 5 \\
2 / 5 \\
4 / 5 \\
5 / 5 \\
5 / 5 \\
3 / 5\end{array}$ & $\begin{array}{l}\text { sterigmatocystin } \\
\text { sterigmatocystin } \\
\text { sterigmatocystin }\end{array}$ & . \\
\hline E. quadrilineata & $\begin{array}{l}\text { 83-Ir-10-1 } \\
83-\mathrm{Ir}-4-7 \\
83-\mathrm{Ir}-4-9 \\
83-\mathrm{Ir}-4-10 \\
83-\mathrm{Ir}-4-11 \\
83-\mathrm{Ir}-4-14 \\
83-\mathrm{Ir}-8-2 \\
83-\mathrm{Ir}-8-5\end{array}$ & $\begin{array}{l}5 / 5 \\
5 / 5 \\
4 / 5 \\
4 / 5 \\
5 / 5 \\
2 / 5 \\
3 / 5 \\
4 / 5\end{array}$ & $\begin{array}{l}\text { EQ-1 } \\
\text { EQ-1 } \\
\text { EQ-1 } \\
\text { EQ-1 } \\
\text { EQ-1 } \\
\text { EQ-1 } \\
\text { EQ-1 } \\
\text { EQ-1 }\end{array}$ & \\
\hline E. variecolor & $83-\operatorname{Ir}-10-2$ & $5 / 5$ & asteltoxin & \\
\hline E. acristata & $83-I r-7-2$ & $5 / 5$ & & \\
\hline E. rugulosa & $83-I r-4-8$ & $1 / 5$ & & \\
\hline Aspergillus flavus & $\begin{array}{l}83-I r-6-1 \\
83-I r-5-4\end{array}$ & - & $\begin{array}{ll}\text { aflatoxins } \mathrm{B}_{1}, \mathrm{~B}_{2} \\
\text { aflatoxins } \mathrm{B}_{1}, \mathrm{~B}_{2}\end{array}$ & \\
\hline A. caespitosus & $\begin{array}{l}83-\operatorname{Ir}-4-4 \\
83-I r-4-5\end{array}$ & $\begin{array}{l}4 / 5 \\
0 / 5\end{array}$ & verruculogen, fumitremorgin B & \\
\hline A. fumigatus & $\begin{array}{l}83-\mathrm{Ir}-3-4 \\
83-\mathrm{Ir}-5-12 \\
83-\mathrm{Ir}-9-1 \\
83-\mathrm{Ir}-3-5 \\
83-\mathrm{Ir}-7-4\end{array}$ & $\begin{array}{l}5 / 5 \\
1 / 5 \\
- \\
-\end{array}$ & $\begin{array}{c}\text { verruculogen, fumitremorgin B } \\
\text { "I } \\
\prime \prime \\
\prime \prime\end{array}$ & \\
\hline
\end{tabular}

* $500 \mathrm{mg} / \mathrm{kg}$, intraperitoneal administration

Table 2. Lethal toxicity of AcOEt extracts to mice

\begin{tabular}{|c|c|c|c|c|c|}
\hline Species & Strains di & died/used* & Species & Strains $\quad d$ & died/used* \\
\hline Chaetomium gracile & $83-\operatorname{Ir}-4-12$ & $1 / 3$ & Podospora sp. & $83-\operatorname{Ir}-6-3$ & $2 / 3$ \\
\hline \multirow[t]{2}{*}{ C. megalocarpum } & $83-\operatorname{Ir}-5-2$ & $3 / 3$ & Ascodesmis sp. & $83-\operatorname{Ir}-9-5$ & $3 / 3$ \\
\hline & $83-\operatorname{Ir}-5-4$ & $3 / 3$ & Gymnoascus sp. & 83-Ir-sheep & p $\quad 2 / 3$ \\
\hline C. murorum & $83-\operatorname{Ir}-5-1$ & - & Microascus sp. & $83-I r-6-4$ & $3 / 3$ \\
\hline \multirow{3}{*}{ Chaetomium sp. } & $83-\operatorname{Ir}-5-15$ & $3 / 3$ & Thermoascus sp. & $83-\mathrm{Ir}-2$ & $5 / 5$ \\
\hline & $\begin{array}{l}83-\mathrm{Ir}-2-2 \\
83-\mathrm{Ir}-37^{\circ} \mathrm{C}\end{array}$ & $\begin{array}{c}1 / 3 \\
-\end{array}$ & $\begin{array}{l}\text { Melanocarpus } \\
\text { albomyces }\end{array}$ & $83-\mathrm{Ir}-37^{\circ} \mathrm{C}$ & $3 / 3$ \\
\hline & $\begin{array}{l}83-I r-D-1 \\
83-I r-5-6\end{array}$ & $\frac{-}{2 / 2}$ & $\begin{array}{c}\text { Lasiobolidium } \\
\text { orbiculoides }\end{array}$ & $83-\operatorname{Ir}-7-8$ & $2 / 3$ \\
\hline \multirow[t]{2}{*}{ Corynascus sepedonium } & $83-\operatorname{Ir}-1-1$ & $3 / 3$ & Khuskia oryzae & $83-\mathrm{Ir}-2-3$ & $2 / 3$ \\
\hline & $83-\operatorname{Ir}-2-13$ & $1 / 3$ & Trichurus spiralis & $83-\operatorname{Ir}-2-12$ & $3 / 3$ \\
\hline Chaetomidium fimeti & $83-\operatorname{Ir}-2-8$ & $2 / 3$ & T. dendrocephalus & $83-I r-1-8$ & $2 / 3$ \\
\hline \multirow[t]{2}{*}{ Ascotricha bosei } & $83-\operatorname{Ir}-6-1$ & $2 / 3$ & & $84-\operatorname{Ir}-18-1$ & $2 / 3$ \\
\hline & $83-I r-5-14$ & $1 / 3$ & & $84-\mathrm{Ir}-18$ & $1 / 3$ \\
\hline
\end{tabular}

* $500 \mathrm{mg} / \mathrm{kg}$, intraperitoneal administration 
Table 3. Physicochemical propeties of EQ-1

colorless prisms, $\mathrm{mp} 243-245^{\circ} \mathrm{C}$ (dec.)

Tests for elements: $\mathrm{N}(+), \mathrm{S}(+)$, halogen $(-)$

IR $\mathrm{KBr} \mathrm{cm}^{-1}: 3420,1728,1683,1608,1515,1273$

UV $\lambda_{\max }^{\mathrm{CHCl}_{3}} \mathrm{~nm}(\varepsilon): 246(12700), 261$ (11300), 284.5 (6300)

Mass $\mathrm{m} / \mathrm{z}: 534\left(\mathrm{M}^{+}\right), 516,288,271,289,152$

${ }^{1} \mathrm{H}-\mathrm{NMR}$ in $\mathrm{CDCl}_{8} \delta_{\mathrm{H}}: 7.90(1 \mathrm{H}, \mathrm{d}, \mathrm{J}=2.5), 7.79\left(1 \mathrm{H}, \mathrm{dd}, \mathrm{J}_{1}=8.9, \mathrm{~J}_{2}=1.8\right), 7.79(1 \mathrm{H}, \mathrm{s})$, $7.07\left(1 \mathrm{H}, \mathrm{dd}, \mathrm{J}_{1}=7.0, \mathrm{~J}_{2}=2.4\right), 7.05(1 \mathrm{H}, \mathrm{d}, \mathrm{J}=7.9), 6.94(1 \mathrm{H}, \mathrm{d}, \mathrm{J}=7.9), 6.91(1 \mathrm{H}$, $\mathrm{d}, \mathrm{J}=1.2), 6.39(1 \mathrm{H}, \mathrm{s}), 6.34\left(1 \mathrm{H}, \mathrm{dd}, \mathrm{J}_{1}=8.6, \mathrm{~J}_{2}=2.4\right), 5.70\left(1 \mathrm{H}, \mathrm{dd}, \mathrm{J}_{1}=7.3, \mathrm{~J}_{2}=2.4\right)$, $5.52(1 \mathrm{H}, \mathrm{d}, \mathrm{J}=1.2), 5.42(1 \mathrm{H}, \mathrm{d}, \mathrm{J}=12.2), 4.99(1 \mathrm{H}, \mathrm{s}), 4.96-4.88(2 \mathrm{H}), 4.85(1 \mathrm{H}$, $\mathrm{d}, \mathrm{J}=13.2), 4.01(3 \mathrm{H}, \mathrm{s}), 3.42(3 \mathrm{H}, \mathrm{s})$

E. quadrilineata $83-\mathrm{Ir}-4-7$

rice $5 \mathrm{~kg}$
moldy rice

AcOEt

extracts $46 \mathrm{~g}$ silica gel column chromatog. ${ }^{* 1}$

hexane-acetone $(1: 1)$

fr. $38-48,3.13 \mathrm{~g}, 3 / 3^{* 2}$ preparative TLC*3 $\mathrm{EQ}-1,3 / 3^{* 4}$

Fig. 1. Isolation of toxic metabolites from E. quadrilineata strain No. 83-Ir-4-7

*1 Wako gel C-200, $500 \mathrm{~g}$

$* 2 \quad 250 \mathrm{mg} / \mathrm{kg}$, i. p.

*8 Kieselgel $\mathrm{F}_{254}$ type 60, hexaneacetone $(1: 1)$

*4 $100 \mathrm{mg} / \mathrm{kg}$, i. p.

キスから Fig. 1 のようにカラムクロマト preparative TLC によって EQ-1 と仮称する毒性物質を単 離した. EQ-1 の物理化学的性質を Table 3 K示す. $\mathrm{EQ}-1$ は $\mathrm{N}, \mathrm{S}$ を含みその化学構造について検討中 であるが, NMR スペクトルデータなどから複雑な構 造が予想されている.

TLC 検索の結果, 2 株の Aspergillus flavus に aflatoxins $\mathrm{B}_{1}, \mathrm{~B}_{2}, A$. caespitosus, A. fumigatus 全株に verruculogen, fumitremorgin $B$ の生産が茨め られた。他に今までに成分研究が報告されていない
Corynascus sepedonium, Microascus sp., Thermoascus sp., Melanocarpus albomyces, Trichurus spiralis, T. dendrocephalus などに毒性が認められ た.

イラクの土壤より分離した菌は今まで 検索を行な った国内の土塨菌と比較して 毒性株の出現頻度は明 らかに高くまた TLC 検索で aflatoxin をはじめ sterigmatocystin, asteltoxin, fumitremorgin など種々 のマイコトキシンの生産性が高頻度にみられた。さら に今まで比較的強い毒性を示した菌のながは化学的 研究の行なわれていないあのが含まれており，今後新 しいマイコトキシンの分離が推測される.

\section{謝辞}

土塨試料を提供して下さったイラク・バスラ大学の S.K. Abdullah 博士, 分離菌の一部について同定い ただいた国立衛生試験所真菌室長 宇田川俊一博士に 感謝致します。

\section{引用文献}

1) Yamazaki, M., Fujimoto, H., Kawasaki, T.: Chem. Pharm.Bull., 28, 245 (1980).

2) Yamazaki, M., Okuyama, E., Kobayashi, M., Inoue, H.: Tetrahedron Lett., 22, 135 (1981).

3) Yamazaki, M., Maebayashi, Y.: Chem. Pharm. Bull., 30, 514 (1982).

4) Joffe, A.Z.: Mycologia, 60, 904 (1968).

5) Horie, Y., Yamazaki, M.: Trans. mycol. Soc. Japan, 22, 113 (1981). 